
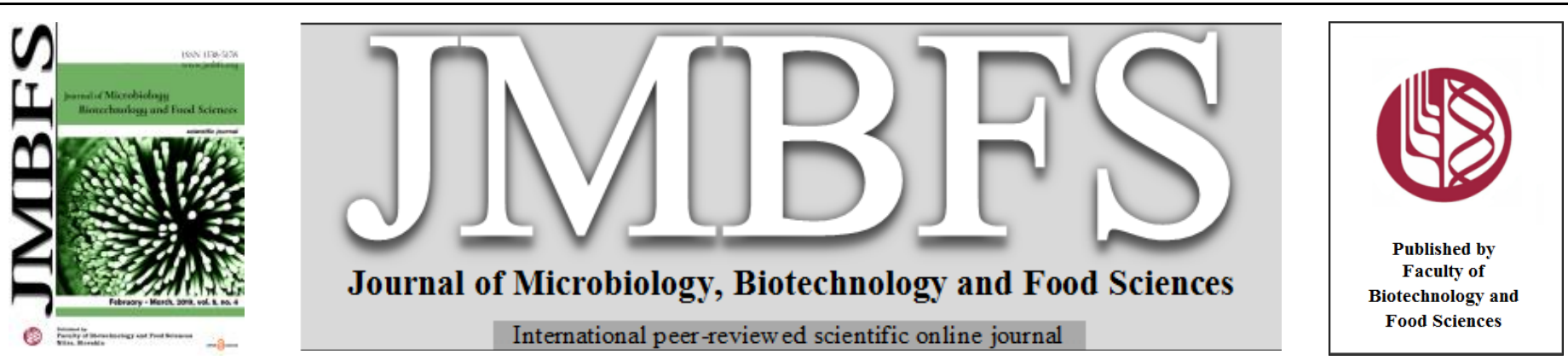

\title{
INFLUENCE OF ADDITIVE PREMIX, WHEY PROTEINS, EXTRUDED AND GERMINATED FLOUR ON GLUTEN FREE DOUGH RHEOLOGICAL PARAMETERS AND FLATBREAD CHARACTERISTICS: A MIXTURE DESIGN APPROACH
}

\author{
Sonal P. Patil, Shalini S. Arya*
}

Address(es):

Food Engineering and Technology Department, Institute of Chemical Technology, Matunga, Mumbai, India 400019.

*Corresponding author: shalu.ghodke@ gmail.com

doi: 10.15414/jmbfs.2019.8.5.1198-1204

ARTICLE INFO

Received 25. 6. 2018

Revised 10.1.2019

Accepted 10. 1.2019

Published 1. 4. 2019

Regular article

OPEN $\partial_{\text {ACCESS }}$

\begin{abstract}
Additives, elastic proteins and flour modification treatments such as germination and extrusion help in the enhancement of the viscoelastic as well as subjective properties of a dough system and flatbread characteristics. Hence, in the present study efforts were made to substitute the gluten free formulation with modified flours as well as elastic proteins and additives. Mixture design approach was used for the purpose using central composite design. Response variables were dough rheological parameters like stickiness and strength along with flatbread characteristics like $L$ value, tear force and extensibility. Regression equations were developed to predict the responses of dough rheological parameters and flatbread characteristics. 3D plots were drawn to understand the behavior of these responses. Optimised levels were 1.5\% additive premix, $10 \%$ extruded flour, $20 \%$ germinated flour and 5\% whey protein that resulted in $39.09 \mathrm{~g}$ dough stickiness, $2.14 \mathrm{~g}$ dough strength, $40.9 \mathrm{~L}$ value, $224.67 \mathrm{~g}$ tear force and $1.70 \mathrm{~mm}$ extensibility. Principle component analysis showed significant relationship between dough rheological parameters (dough stickiness, dough strength) and flatbread characteristics ( $L$ value, tear force extensibility).
\end{abstract}

Keywords: Gluten free, flatbread, extruded flour, germinated flour, whey protein, principal component analysis

\section{INTRODUCTION}

Gluten network is a key structure in a flatbread dough system (Abbasi $\boldsymbol{e t}$ al., 2012). This network is responsible for various technological qualities such as elasticity, mass cohesion, and moisture, besides, desirable sensory characteristics like softness, texture and uniformity (Abbasi et al., 2012). All these characteristics are very important in case of flatbread

It has been shown in various studies that addition of additives, proteins and flour modification treatments such as germination (Yousif et al., 2014) and extrusion (Gat and Ananthnarayan., 2015a) help in the enhancement of the viscoelastic as well as subjective properties of a dough system (Gallagher et al., 2003). Hence, the present study was aimed at substituting the gluten free formulation with modified flours as well as elastic proteins and additives.

Various reports are available where extruded flours have been successfully employed in the preparation of traditional (Ananthnarayan., 2018a, Ananthnarayan., 2018b) and bakery products. It is being seen that extrusion process promotes lipid complexation with starch and/or proteins due to the high temperature used and brings out alterations in textural parameters in dough system. In one study (Roman et al., 2015), extruded wheat flour has been utilized in the preparation of cake and improvements in the textural quality of cake was observed. Martinez et al. (Martinez et al., 2014) also extruded rice flour and incorporated in gluten free bread and reported increased water absorption but decreased textural attributes of gluten free cake. Ozola et al. (Ozola et al., 2012) used extruded maize flour for the development of gluten free breads and reported better porosity of gluten free bread. Jafari et al. (Jafari $\boldsymbol{e t}$ al., 2018) used extruded composite flour in the formation of composite sorghum rice bread and found improvements in bread flavor and overall acceptability.

Germination process is very well known as it brings out improvements in protein digestibility and also aids to decrease flatulence. Yousif et al. (Yousif et al., 2014) have studied use of germinated legume (lupin and chickpea) flour into gluten free bread. The gluten free breads thus made were more acceptable in terms of sensory properties. Further delay in the retrogradation rate of gluten free bread was observed due the enhanced water absorption as a result of addition of germinated legumes. Gallagher et al. (Gallagher et al., 2003) have reported the augmentation in technical as well as nutritional qualities of gluten free bread with the addition of whey protein powder.
Despite of all the above stated researches, the combined use of all these modified flours and proteins, additives in gluten free flatbread (GFFB) haven't yet been reported. Hence, the present study deals in improving the quality of gluten-free formulated flatbread by using various modified flours (extruded flour, germinated flour, whey protein) along with and to optimize a proportional levels thereof suitable for flatbread making.

\section{MATERIALS AND METHODS}

Wheat (Triticum aestivum) flour (Aashirvaad, ITC ${ }^{\mathrm{TM}}$, Mumbai, Maharashtra, India), rice (Oryza sativa) flour (Bhagirathi ${ }^{\mathrm{TM}}$, Mumbai, Maharashtra, India), sorghum (Sorghum bicolor) flour (Bhagirathi ${ }^{\mathrm{TM}}$, Mumbai, Maharashtra, India), moong (Vigna radiate) flour (Swad ${ }^{\mathrm{TM}}$, Mumbai, Maharashtra, India), water chestnut (Trapa natans) flour (Swad ${ }^{\mathrm{TM}}$ Mumbai, Maharashtra, India) were purchased from local market of Mumbai. Unripe banana (Musa paradisiaca) flour (Mahila Gruh Udyog ${ }^{\mathrm{TM}}$, Jalgaon, India) was purchased from Jalgaon banana market. All the flours were sieved $(60 \mathrm{mesh})$ and then used for analysis. Whey proteins (Royal Ingredients, Mumbai, Maharashtra, India ${ }^{\mathrm{TM}}$ ) were also purchased. Additives (guar gum, xanthan gum and glycerol monostearate) were gifted by Royal Ingredients, Mumbai, Maharashtra, India.

\section{Preparation of Extruded flour}

Gluten free formulation consisted of rice (60\%), sorghum (10\%), unripe banana $(5 \%)$, water chestnut $(15 \%)$ and moong flour $(10 \%)$. Extrusion was performed as suggested by Gat and Ananthnarayan (Gat and Ananthnarayan., 2016) using a laboratory-scale-co-rotating twin-screw extruder (KETSE 20/40 Brabender $\mathrm{GmbH}$ and Co. KG, Duisburg, Germany) was used for extrusion. It has barrel length to diameter ratio of 20:1. Extrusion conditions were feed moisture 16\% and die temperature $160^{\circ} \mathrm{C}$. Extrudates were ground to fine powder and sieved through 60 mesh and used for preparation of flatbread.

\section{Preparation of germinated flour}

Moong seeds were cleaned for all foreign materials present if any. These were then washed with water. $1 \mathrm{~kg}$ of moong seeds were soaked in 5 liters of water. 
Soaking was carried out at $30 \pm 2{ }^{\circ} \mathrm{C}$ for $12 \mathrm{hrs}$. The water was drained and seeds germination was carried under a wet muslin cloth in the dark for 2 and 3 days at ambient environmental conditions. The sprouted seeds were collected and dried in an air dryer oven at $50 \pm 5{ }^{\circ} \mathrm{C}$ for $16-18 \mathrm{~h}$ (Chavan et al., 2018). These were then ground to fine powder and sieved through 60 mesh and used for preparation of flatbread.

\section{Preparation of additive premix}

Additive premix consisted of guar gum ( $0.8 \%)$, xanthan gum $(0.3 \%)$ and glycerol mono-stearate $(0.9 \%)$ based on flour. This premix was optimized in our previous studies

Proximate composition
Protocols for determining moisture, ash, protein and fat were AOAC (AOAC.,1995), AOAC (AOAC.,1995), AACC (AACC.,2000), AOAC (AOAC.,2006) respectively. Carbohydrate content was calculated by difference.

\section{Experimental design}

Mixture design approach employed the central composite design for the purpose Independent components of the mixture included additives (A), extruded flour (B), germinated flour (C) and whey protein (D). Preliminary experiments (varying one ingredient at a time and based on the optimum level) were carried out to select the actual levels of these independent variables. Outline of experimental design with the coded and uncoded levels is presented in table 1. Response variables were system dough rheological parameters like dough stickiness and strength along with flatbread characteristics like $L$ value, tear force and extensibility. Design-Expert 7.0.0 was employed for the purpose.

Table 1 Experimental layout employed in central composite design to study the effect of added modified flours on dough and flatbread characteristics

\begin{tabular}{|c|c|c|c|c|c|c|c|c|}
\hline \multirow{2}{*}{ Run } & \multicolumn{2}{|l|}{ Additives } & \multicolumn{2}{|c|}{ Extruded flour } & \multicolumn{2}{|c|}{ Germinated flour } & \multicolumn{2}{|l|}{ Whey protein } \\
\hline & Actual value & Coded value & Actual value & Coded value & Actual value & Coded value & Actual value & Coded value \\
\hline 1 & 1.5 & 1 & 20 & 1 & 10 & -1 & 5 & -1 \\
\hline 2 & 1 & 0 & 15 & 0 & 15 & 0 & 7.5 & 0 \\
\hline 3 & 0 & -2 & 15 & 0 & 15 & 0 & 7.5 & 0 \\
\hline 4 & 1.5 & 1 & 20 & 1 & 10 & -1 & 10 & 1 \\
\hline 5 & 0.5 & -1 & 20 & 1 & 10 & -1 & 5 & -1 \\
\hline 6 & 1.5 & 1 & 10 & -1 & 10 & -1 & 5 & -1 \\
\hline 7 & 0.5 & -1 & 20 & 1 & 10 & -1 & 10 & 1 \\
\hline 8 & 1 & 0 & 25 & 2 & 15 & 0 & 7.5 & 0 \\
\hline 9 & 0.5 & -1 & 10 & -1 & 20 & 1 & 5 & -1 \\
\hline 10 & 1 & 0 & 5 & -2 & 15 & 0 & 7.5 & 0 \\
\hline 11 & 0.5 & -1 & 10 & -1 & 20 & 1 & 10 & 1 \\
\hline 12 & 1.5 & 1 & 20 & 1 & 20 & 1 & 10 & 1 \\
\hline 13 & 1 & 0 & 15 & 0 & 15 & 0 & 2.5 & -2 \\
\hline 14 & 0.5 & -1 & 20 & 1 & 20 & 1 & 5 & -1 \\
\hline 15 & 1 & 0 & 15 & 0 & 25 & 2 & 7.5 & 0 \\
\hline 16 & 0.5 & -1 & 10 & -1 & 10 & -1 & 5 & -1 \\
\hline 17 & 2 & 2 & 15 & 0 & 15 & 0 & 7.5 & 0 \\
\hline 18 & 0.5 & -1 & 20 & 1 & 20 & 1 & 10 & 1 \\
\hline 19 & 1.5 & 1 & 10 & -1 & 20 & 1 & 5 & -1 \\
\hline 20 & 1 & 0 & 15 & 0 & 15 & 0 & 7.5 & 0 \\
\hline 21 & 1.5 & 1 & 10 & -1 & 10 & -1 & 10 & 1 \\
\hline 22 & 0.5 & -1 & 10 & -1 & 10 & -1 & 10 & 1 \\
\hline 23 & 1.5 & 1 & 10 & -1 & 20 & 1 & 10 & 1 \\
\hline 24 & 1 & 0 & 15 & 0 & 15 & 0 & 12.5 & 2 \\
\hline 25 & 1 & 0 & 15 & 0 & 15 & 0 & 7.5 & 0 \\
\hline 26 & 1 & 0 & 15 & 0 & 15 & 0 & 7.5 & 0 \\
\hline 27 & 1 & 0 & 15 & 0 & 5 & -2 & 7.5 & 0 \\
\hline 28 & 1.5 & 1 & 20 & 1 & 20 & 1 & 5 & -1 \\
\hline 29 & 1 & 0 & 15 & 0 & 15 & 0 & 7.5 & 0 \\
\hline 30 & 1 & 0 & 15 & 0 & 15 & 0 & 7.5 & 0 \\
\hline
\end{tabular}

\section{Dough Rheology}

The method explained by Ghodke (Ghodke., 2009) was used for the assessment of doughs. Stable Micro Systems Texture Analyzer was employed for the evaluation. Dough stickiness $(\mathrm{g})$ and dough strength $(\mathrm{g})$ were determined.

\section{$L$ value}

GFFBs were evaluated for Hunter $L$ (luminoscity) value using Hunterlab colorimeter (Labscan XE, Serial No. LX 17375, USA). D65 light source was used. Samples were placed in a glass cuvette above the light source and covered and readings were taken.

\section{Flatbread texture}

GFFBs were evaluated for tear force (g) according to the method of Ghodke and Ananthanarayan (Shalini and Laxmi., 2007) using TA-XT2i Stable Microsystems texture analyzer. The sample dimensions used were $7 \mathrm{~cm} * 3.5 \mathrm{~cm}$ (length*width). Results were obtained for tear force $(\mathrm{g})$ and extensibility $(\mathrm{mm})$.

\section{RESULTS AND DISCUSSION}

\section{Proximate composition}

Table 2 demonstrates that there is variation in the proximate composition of extruded gluten free flour with that of the original gluten free formulation. And also the variation between the germinated moong flour with that of the moong flour.

Table 2 Proximate composition of modified flours

\begin{tabular}{lcccc}
\hline & GFF & Extruded GFF & Moong flour & Germinated Moong flour \\
\hline Moisture (\%) & $10.411 \pm 0.908$ & $9.96 \pm 0.48$ & $9.74 \pm 1.01$ & $9.45 \pm 0.41$ \\
Protein (\%) & $8.28 \pm 0.144$ & $8.33 \pm 0.19$ & $24.07 \pm 0.69$ & $25.17 \pm 0.27$ \\
Fat (\%) & $2.10 \pm 0.086$ & $1.91 \pm 0.06$ & $1.61 \pm 0.35$ & $1.54 \pm 0.13$ \\
Ash (\%) & $1.73 \pm 0.058$ & $1.73 \pm 0.03$ & $2.92 \pm 0.44$ & $2.78 \pm 0.16$ \\
Carbohydrate (\%) & $77.46 \pm 0.85$ & $78.05 \pm 0.26$ & $61.63 \pm 1.28$ & $61.04 \pm 0.36$ \\
\hline
\end{tabular}

Values are represented as mean \pm SD of three determinations 
The extrusion cooking process causes a remarkable change in the moisture content (Gat and Ananthnarayan., 2015b). The moisture content of raw gluten free formulation was $10.41 \%$, while after extrusion it was significantly decreased to $9.96 \%(\mathrm{p}<0.05)$. As can be seen from the table protein content of gluten free formulation varied from 8.28 to $8.33 \%$ during extrusion cooking. A substantial decrease in fat content of the gluten free formulation was observed during the process of extrusion (from 2.10 to $1.91 \%$ ). This reduction may be because of the extrusion process that promotes lipid complexation with starch and/or proteins due to the high temperature employed (Ortolan et al., 2015). Ash content and carbohydrate content also showed similar composition in both the flours.

The composition of native and germinated moong flour showed varying values of proximate parameters. There was a increase in the protein content of moong flou (from 24.07 to 25.17\%). Such increase was observed by Yousif $e$ al. (Yousif $e t$ al., 2014) during germination of legumes. Similar increase in the protein content in legume seeds due to germination process has also been reported by Hsu et al. (Hsu et al., 1980). They further described the reason behind this is biochemical changes those take place as a result of germination and increases the percentage of free amino acids.

A decrease in fat content from 1.61 to $1.54 \%$ was observed during the course of germination. This might be due to the loss of total solids during soaking. Also the utilization of fats as an energy source for the germination might also be responsible for this decrease. (Yousif et al., 2014).

A decrease in carbohydrate content and ash content was observed during germination. This decrease can be attributed to the loss of water soluble compounds as they leach out and and diffuse in the surrounding soaking water (Ouazib et al., 2016)

\section{Diagnostic checking of fitted models}

All the responses showed values of "Prob > F" less than 0.0500 indicating model terms were significant. The "Lack of Fit F-value" was not significant relative to the pure error which is a good symbol of fitting of model.

\section{Dough stickiness}

The stickiness of the dough is considered to be very important. It plays a crucia role during flattening, rolling and sheeting of flat bread dough. High stickiness values are undesirable as the dough sticks to rolling surfaces while low stickiness yields a poor adhesion property and usually fails to retain the required shape.

The regression equation relating dough stickiness is:

Dough Stickiness $=+36.93+0.35 * \mathrm{~A}-0.12 * \mathrm{~B}+0.031 * \mathrm{C}+0.22 * \mathrm{D}$

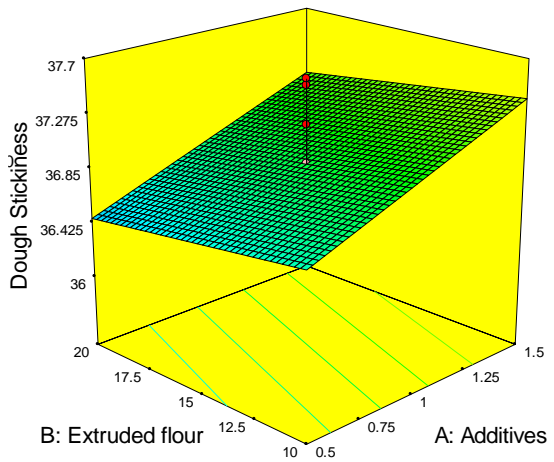

Figure 1a 3 D plot for dough stickiness of gluten free dough as function of extruded flour and additives

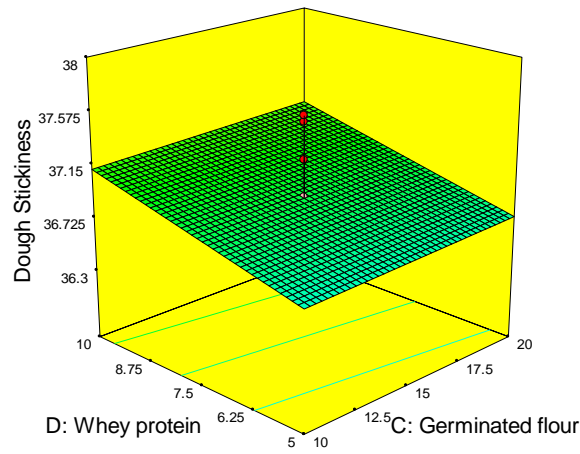

Figure 1b 3 D plot for dough stickiness of gluten free dough as function of whey protein and germinated flour
Figure $1 \mathrm{a}$ and $1 \mathrm{~b}$ is elaborating the dough stickiness trend with respect to modified flours and ingredients. Dough stickiness increased with increase in additives proportion as well as with increase in whey protein. A slight increase was observed with the increasing proportion of germinated flour. This increase in stickiness may be due to the increased water absorption capacity attributed to increased protein content and pentosan content especially non-starch polysaccharides in the composite flour system due to addition of germinated legume flour (Anton and Artfield., 2008). Increase in stickiness values with additives can be assigned to the presence of hydrocolloids in the additive premix. Hydroxyl groups present in hydrocolloids allows more water interactions through hydrogen bonding and hence increased stickiness (Patil snd Arya., 2016).

As can be seen from the figure, an increase in the proportion of whey protein have caused a significant increase in dough stickiness which might be due to water absorption capacity of such proteins or isolates. It has been reported that this capacity is due to their ability to compete for water with other constituents in the dough system. The ability of these proteins to absorb high quantities of water results in changes in dough which yields into the dough with improved characteristics (Gallagher $\boldsymbol{e t}$ al., 2003). This increase in dough stickiness might also be due to the formation of mesoscopic structure in the dough system due to whey proteins (van Riemsdijk et al., 2011).

\section{Dough strength}

Dough strength is a balance of two main properties; extensibility and elasticity. Dough strength affects production characteristics through all of the baking process. It is most critical during shaping. If the dough is too strong, it will be too elastic and difficult to shape. If it's too weak, it will stretch easily, but won't hold its shape during baking (van Riemsdijk et al., 2011).

Dough strength was well explained by the regression equation;

Dough strength $=+2.10+0.048 * \mathrm{~A}-0.012 * \mathrm{~B}+0.066 * \mathrm{C}+0.066 * \mathrm{D}$

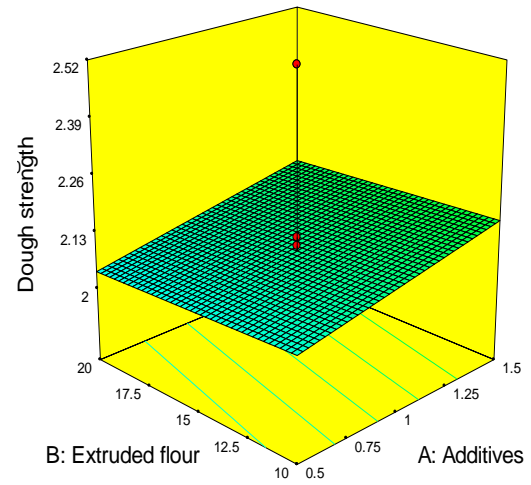

Figure 2a 3 D plot for dough strength of gluten free dough as function of extruded flour and additives

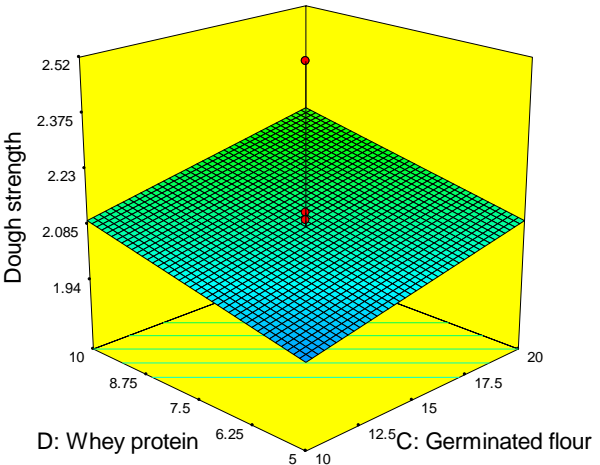

Figure 2b 3 D plot for dough strength of gluten free dough as function of whey protein and germinated flour

Figure $2 \mathrm{a}$ and $2 \mathrm{~b}$ elaborates the bahavior of dough strength with varying ratios of flours and ingredients in mixture. Extruded flour seemed to show quiet negative impact on dough strength while change in the levels of additives tend to be directly proportional to the changes in dough strength. A gradual increase in dough strength was observed with the increase in proportion of dough additives (hydrocolloids and emulsifiers) There are many possible factors involved dough improving effects of hydrocolloids (guar gum and xanthan gum). Hydrocolloids are characterised byt heir molecular structures as well as ionic charges (Kohajdova et al., 2009). Emulsifiers are known to act as strengtheners in dough system. Hydrophobic and hydrophilic residues in emulsifiers allow themselves to interact with flour constituents and water and form complexes. 
Thus they help in reduction of protein molecules repulsion and leads to the aggragate formation which can improve dough strength and allow superior sheeting properties (Demirkesen et al., 2010).

It is also clear from the figure that incresing levels of both germinated flour and whey proteins led to an increase in the dough strength of gluren free formulation. The increased dough textural properties due to the addition of germinated moong flour can be assumed to be due to the increased solubility of proteins. This leads to enhancement of emulsifying capacity and foaming properties (Mostafa $\boldsymbol{e t} \mathbf{a l}$., 1987).

\section{Color of flatbread}

As said by Francis (Francis., 1998), color is crucial in deciding the acceptability of food products before -getting consumed. $L$ (luminosity) value indicates the brightness of the product; higher value of which is requisite. Flatbreads are creamish brown in color when freshly prepared. Color of these flatbreads are considered as one of the important characteristics and has an impact on consumer acceptability of flatbreads. $L$ value indicates lightness of the object. It represents the darkest black at $L^{*}=0$, and the brightest white at $L^{*}=100$ (Giese., 2000)

The regression equation relating color of GFFB is;

$L$ value $=+39.80+0.057 * \mathrm{~A}-0.11 *+0.15 * \mathrm{C}-0.64 * \mathrm{D}+0.089 * \mathrm{~A} * \mathrm{~B}-0.021 * \mathrm{~A} * \mathrm{C}-$ $0.089 * \mathrm{~A} * \mathrm{D}+0.086 * \mathrm{~B} * \mathrm{C}+0.17 * \mathrm{~B} * \mathrm{D}-0.10 * \mathrm{C} * \mathrm{D}+0.15 * \mathrm{~A}^{2}+0.15 * \mathrm{~B}{ }^{2}-5.729 \mathrm{E}-$ $003 * \mathrm{C}^{2}+0.35 * \mathrm{D}^{2}$

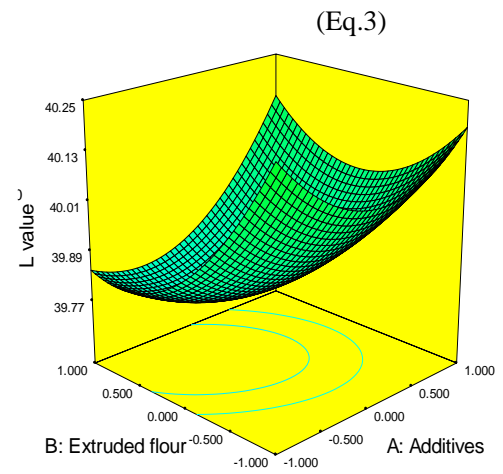

Figure 3a 3 D plot for $L$ value of gluten free flatbread as function of extruded flour and additives

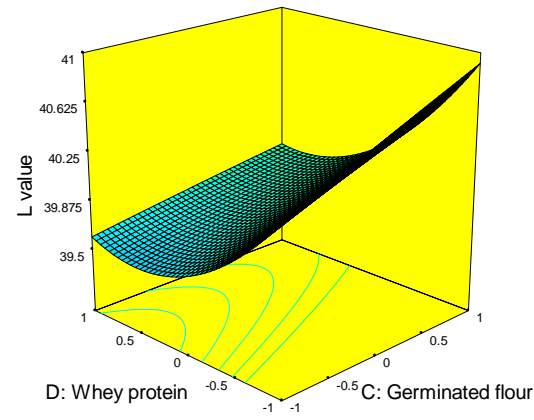

Figure 3b 3 D plot for $L$ value of gluten free flatbread as function of whey protein and germinated flour

Figure $3 \mathrm{a}$ and $3 \mathrm{~b}$ illustrates the behaviour of $L$ value of flatbreads as influenced by the addition of modified flours and additives. Color in baked goods is a result of maillard and caramelization reactions. As seen from figure $8.3 \mathrm{a}, L$ value was found to be having a positive impact due to the addition of additives and germinated moong flour. This increase in luminosity/brightness due to the addition of germinated moong flour could be due to the carotene content of dehulled moong beans after germination (Jyotsna et al., 2014). $L$ value was decreased with increase in extruded flour as well as whey protein. This decrease due to extrusion cooking can be attributed to caramelization or the maillard reaction (Cheftel., 1986). Amino acids and reducing sugars in the raw materia react with each other at high temperature resulting in production of dark product. Menegassi et al. (Menegassi et al., 2011) also have reported a decrease in luminosity ( $L$ value) by the extrusion process

\section{Tear force of flatbread}

Tear strength is the tensile force required to rupture. In simpler terms tear force (or tear strength) is a measure of how well flatbread can withstand the effects of tearing. More specifically however it resists the growth of any cuts when under tension. Lower values of tear force indicates desirable soft flatbread while higher values are undesirable signifying harder flatbread.

Regression equation relating to tear force was;
Tear force $=+256.82-9.77 * \mathrm{~A}+4.63 * \mathrm{~B}-3.02 * \mathrm{C}+2.20 * \mathrm{D}+5.51 * \mathrm{~A} * \mathrm{~B}+1.13 * \mathrm{~A} * \mathrm{C}$ $10.13 * \mathrm{~A} * \mathrm{D}-5.93 * \mathrm{~B} * \mathrm{C}-3.69 * \mathrm{~B} * \mathrm{D}-1.27 * \mathrm{C} * \mathrm{D}$

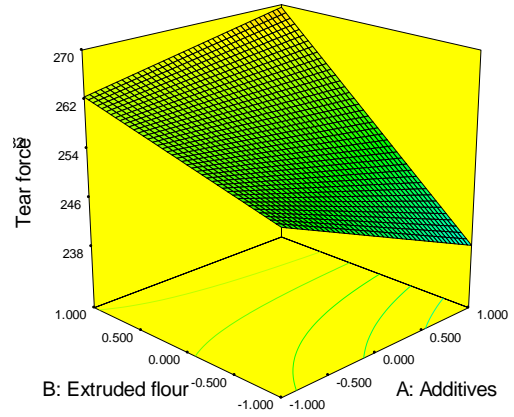

Figure 4a $3 \mathrm{D}$ plot for tear force of gluten free flatbread as function of extruded flour and additives

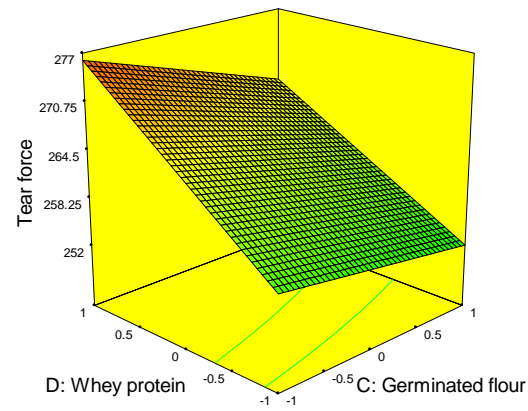

Figure $4 \mathbf{b} 3$ D plot for tear force of gluten free flatbread as function of whey protein and germinated flour

Figure $4 \mathrm{a}$ and $4 \mathrm{~b}$ explains the effect of addition of modified ingredients on tear force of flatbread. It is clear from figure 8.4a that tear force was increased with increasing percentage of extruded flour and whey protein. Gallagher et al. (Gallagher et al., 2003) have reported changes in textural parametrs of the finished produtcs due to the addition of protein concentrates. The increase in tear force with the addition of whey proteins can be attributed to the formation of mesoscopic structure in the dough system with them (van Riemsdijk et al. 2011). Addition of germinated flour led to a slight increase in tear force of GFFBs. Noor Aziah et al. (Aziah et al., 2012) found an increase in the breaking strength of bakery products incorporated with legume flour which might have resulted from the incorporation of protein-rich flour which needs more water to obtain good dough, and the final product thus prepared from high-absorption dough tend to be extremely hard.

Significant decrease in tear force of flatbreads was observed when additives were added in increasing proportion. Patil and Arya (Patil snd Arya., 2016) have stated about this decrease in tear force of flatbread with hydrocolloids addition. They have reported about the weakening effect of hydrocolloids on the starch structure.

\section{Extensibility of flatbreads}

Regression equation relating to extensibility was obtained as; Extensibility $=+1.53+0.19 * \mathrm{~A}+0.021 * \mathrm{~B}+7.500 \mathrm{E}-003 * \mathrm{C}+0.11 * \mathrm{D}$

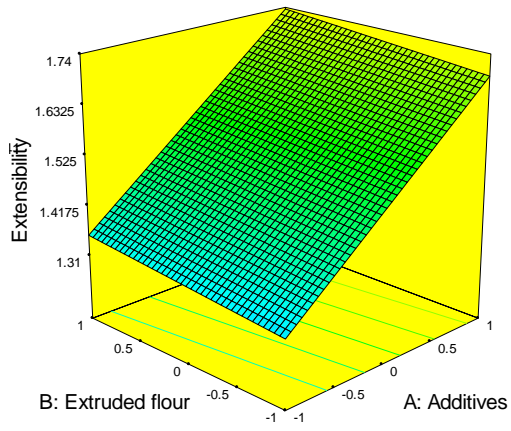

Figure 5a 3 D plot for extensibility of gluten free flatbread as function of extruded flour and additives 


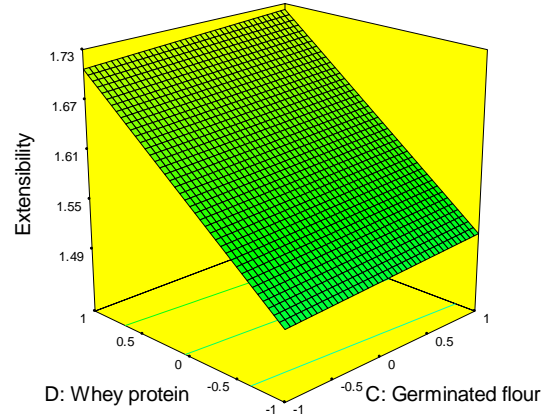

Figure 5b 3 D plot for extensibility of gluten free flatbread as function of whey protein and germinated flour

Figure $5 \mathrm{a}$ and $5 \mathrm{~b}$ explains the bahavior of extensibility in the presence of different modified flou and ingredients. It is clearly seen from these figures that extensibiloity was increased tremendously with the increased proportion of additives and whey protein whereas there was slight or almost negligible change was observed in the bahavior of extensibility with respect to modified flours like extruded and germinated flour.
The increase in extensibility could be attributed to the presence of hydrocolloids and emulsifiers in the additive premix. Emulsifiers (glycerol monostearate) are known to react with starches to form complexes and structural network development which eventually results in better textural quality of the product (Nuessli et al., 2000). As reported earlier, (van Riemsdijk et al., 2011) whey proteins were able to create mesoscopic structure in the dough system. Bilgin $e$ al.(Bilgin et al., 2006) have also reported textural improvements due to the dough strengthening effect of the milk solids from whey proteins which might have led to the increase in extensibility of the GFFB.

\section{Optimisation of independent variables and validation of model}

For the optimization, the goals were selected as elaborated in table 3 for the responses viz; maximised dough stickiness, dough strength, L value and minimised tear force and extensibilit. By using the given criteria, the solution obtained was additives (1.5\%), extruded flour (10\%), germinated flour (20\%) and whey proteins $(6 \%)$. Flatbreads were prepared based on solution obtained and analysed for the responses. The measured response values were very close to the predicted values, confirming the adequacy of the models. Also, the validation of the model was reconfirmed by the lower chi square values as depicted in table 3 . Thus, the given solution was found to be the optimum one with the specified levels of modified flours and ingredients for the prepeartion of GFFB.

$\underline{\text { Table } 3 \text { Model validation and optimization of constraints for central composite design }}$

\begin{tabular}{|c|c|c|c|c|c|c|}
\hline \multirow{2}{*}{ Constraints } & \multirow{2}{*}{ Goal } & \multicolumn{2}{|c|}{ Limits } & \multirow{2}{*}{$\begin{array}{c}\text { Model } \\
\text { Predicted } \\
\text { Value } \\
\end{array}$} & \multirow{2}{*}{$\begin{array}{l}\text { Experimental } \\
\text { Value }\end{array}$} & \multirow{2}{*}{$\begin{array}{c}\text { Chi square } \\
\text { value }\end{array}$} \\
\hline & & Lower & Upper & & & \\
\hline Additives & is in range & 0.5 & 1.5 & 1.5 & 1.5 & - \\
\hline Extruded flour & is in range & 10 & 20 & 10.01 & 10 & - \\
\hline Germinated flour & is in range & 10 & 20 & 20 & 20 & - \\
\hline Whey protein & is in range & 5 & 10 & 6.48 & 6 & - \\
\hline $\begin{array}{l}\text { Dough stickiness } \\
\text { (g) }\end{array}$ & Maximize & 36.05 & 39.65 & 37.35 & $39.09 \pm 0.68$ & 0.87 \\
\hline $\begin{array}{l}\text { Dough strength } \\
\text { (g) }\end{array}$ & Maximize & 1.87 & 2.51 & 2.16 & $2.14 \pm 0.18$ & 0.98 \\
\hline$L$ value & Maximize & 38.85 & 41.92 & 41.53 & $40.90 \pm 0.29$ & 0.98 \\
\hline Tear force (g) & Maximize & 220 & 281.76 & 246.73 & $224.67 \pm 3.86$ & 0.05 \\
\hline $\begin{array}{l}\text { Extensibility } \\
(\mathbf{m m})\end{array}$ & Minimize & 1.11 & 1.98 & 1.60 & $1.70 \pm 0.07$ & 0.99 \\
\hline
\end{tabular}

\section{Principal component analysis}

Principal Component Analysis (PCA) was used to visualize the variation between the variables i.e. independent (additives, extruded and germinated flours and whey proteins) and dependent (Dough stickiness, dough strength, L value, tear force. This statistical method is very effetcive to study complex data which involves reduction of large number of variable to fewer principal components (PC). The eigenvalues for successive factors are displayed on a so-called "screeplot", Figure 6. The number of factors with eigenvalues $>1$ were were chosen by application of Kaiser and Rice's rule (Otto., 1999).

The PCA plots provide a general idea about the variation between the modified flours and ingredients as well as their association with responses. The distance between the locations of any two variables on the plot is directly proportional to the degree of difference or similarity between them. The variables whose curves lie close to each other on the plot were positively correlated while those whose curves run in opposite directions were negatively correlated.

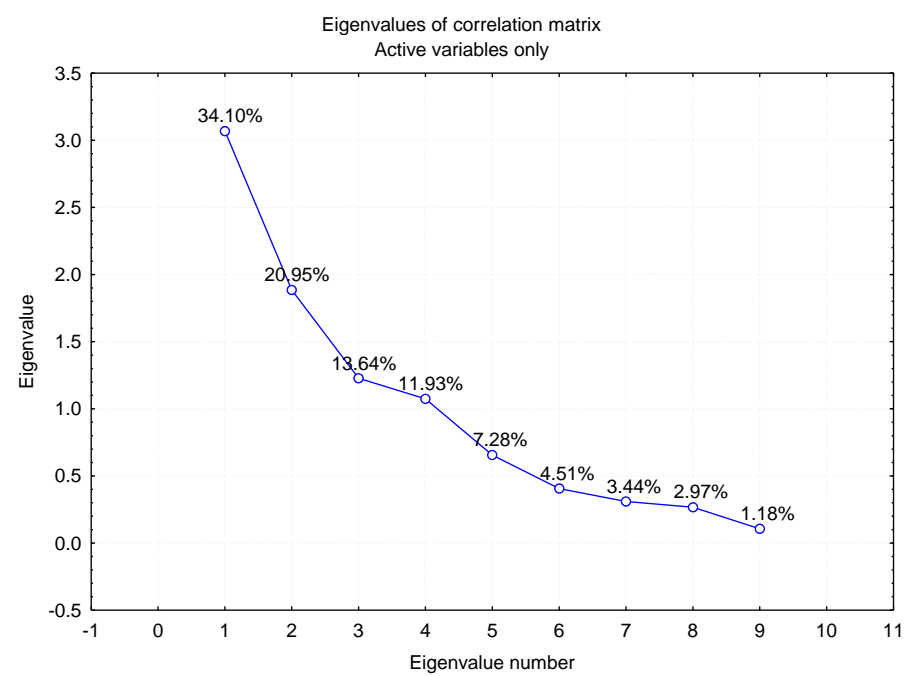

Figure 6 Principal component analysis: Scree plot showing Eigen values for the extracted principal components

Figure 6 shows the scree plot of principle components explaining the variability between the data. As can be seen from the figure, there are 9 principle components extracted. First two components in total represents $55.05 \%$ of the variability hence, here it is necessary to consider third pronciple component also in order to explain the data to more accuracy.

This analysis showed two axes explaining the essential variability that were axis 1 and 2. The first and the second PCs described 34.1 and $20.95 \%$ of the variance respectively. Together, the first two PCs represented $55.05 \%$ of the total variability followed by third PC explaining $13.64 \%$ of the variability. As shown in figure $7 \mathrm{a}, \mathrm{PC} 1$ (principal component 1) separates tear force along with extruded flour from all the other variableswhich implies that except extruded flour all the other variables are negatively correlated with tear force of GFFB. 
This principal component places whey protein alongwith dough properties and extensibility in a single quadrent explaining their direct relationship with each other due to their enhanced protein qualities. Also, resemblance between germinated flour and additives has been explained by this PC which shows that the addition of both these ingredients brings out similar alterations in GFFB

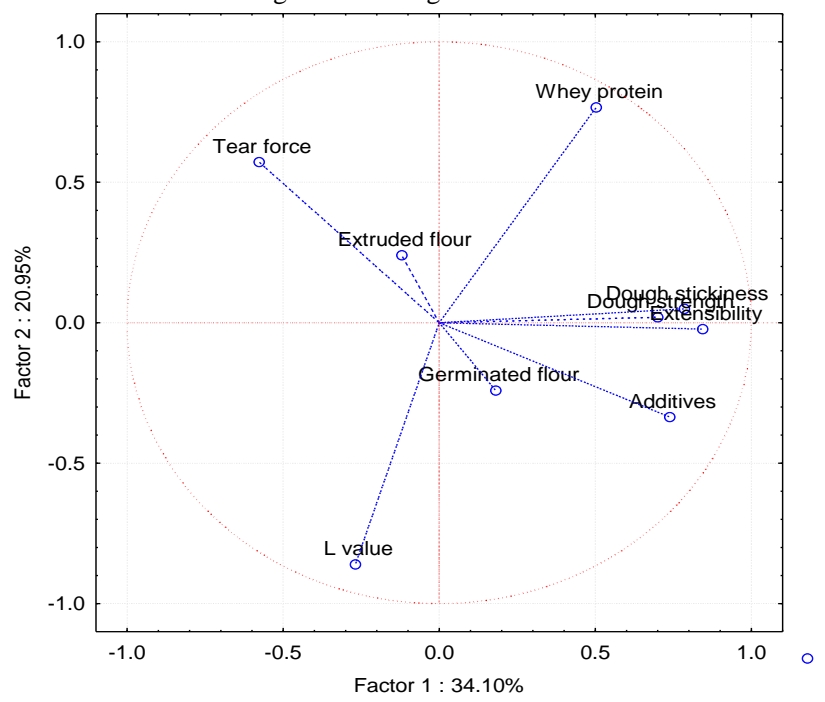

Figure 7a Principal component analysis: Loading plot of dependent and independent variables on PC 1 and PC 2

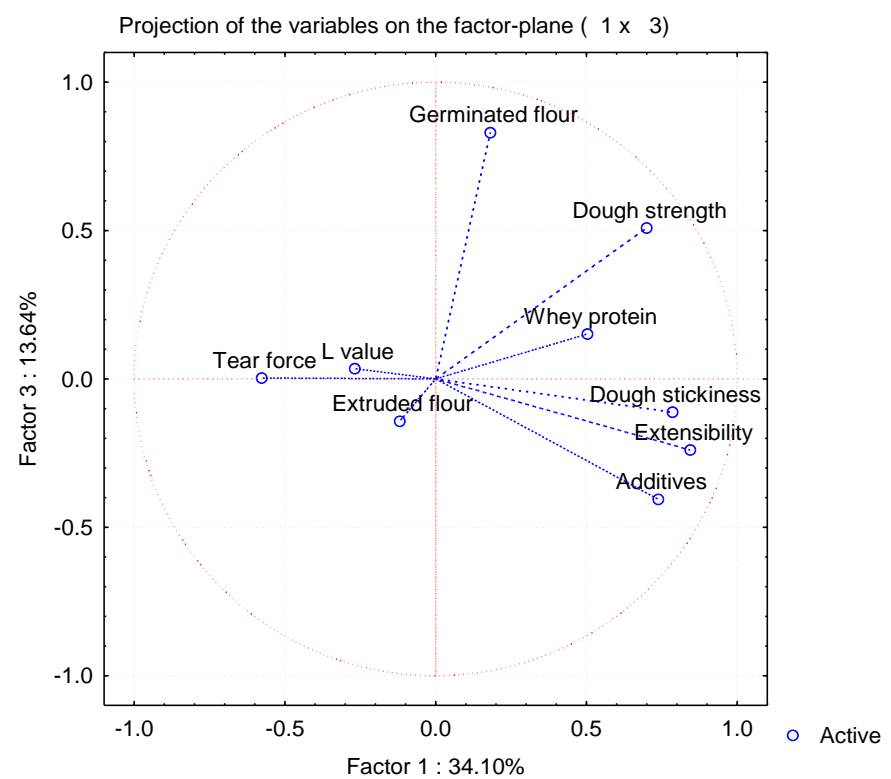

Figure 7b Principal component analysis: Loading plot of dependent and independent variables on PC 1 and PC 3

Second PC places L value far away from others showing negative impact of other ingredients and correlation from others. It places tear force and whey protein in a single quadrent which explaine how tear force increases with increasing whey proteins. Carefully seen at the figure, there is a formation of cluster from between dough properties and extensibility. This shows all these properties of GFFB are closely associated with each other.

As can be seen from figure $7 \mathrm{~b}$, PC 1 separates dough stickiness, dough strength extruded flour and additives from whey proteins, germinated flour and other parameters. And PC 3 separates tear force, L values and extruded flour from all the dough characteristics alongwith whey protein, germinated flour and additives also extensibility. It shows the positive influence of whey protein, germinated flour on dough and flat bread characterostics owing to the presence of proteins in them (Gallagher et al., 2003).

\section{CONCLUSION}

It was confirmed that the mixture design is an effective tool to study the effect of varying proportions of modified flours and ingredients on the quality of GFFB and optimization of the proportions thereof for making flatbreads suitable for coeliac patients. Flatbread characteristics were found to be affected due to the addition of these flours and ingredients. Improvement in dough stickiness, strength and flatbread color and texture was observed. Addition of higher levels of extruded flour resulted in darkening of the final flatbread. Whey protein led to an increase in tear force of the GFFB. Optimised levels obtained were additives $(1.5 \%)$, extruded flour $(10 \%)$, germinated flour $(20 \%)$ and whey protein $(5 \%)$ resulted in flatbread with dough stickiness $(39.09 \mathrm{~g})$, dough strength $(2.14 \mathrm{~g}), \mathrm{L}$ value (40.9), tear force $(224.67 \mathrm{~g})$ and extensibility $(1.70 \mathrm{~mm})$.

Acknowledgement: Authors are grateful to UGC (University Grants Commission) for providing economical support.

Conflicts of interest: Authors do not have any conflicts of interest

\section{REFERENCES}

AACC, I. 2000. Approved Methods of the AACC. Association of Cereal Chemists, St. Paul

ABBASI, H., ARDABILI, S., SEYEDAIN, M. EMAM-DJOMEH, Z., MOHAMMADIFAR, M. A., ZEKRI, M., AGHAGHOLIZADEH, R. 2012 Prediction of extensograph properties of wheat-flour dough: artificial neural networks and a genetic algorithm approach. Journal of texture studies, 43(4), 326-337. https://doi.org/10.1111/j.1745-4603.2011.00342.x

ANANTHANARAYAN, L., GAT, Y., KUMAR, V., PANGHAL, A., \& KAUR, N. 2018a. Extruded black gram flour: Partial substitute for improving quality characteristics of Indian traditional snack. Journal of Ethnic Foods, 5(1), 54-59. https://doi.org/10.1016/j.jef.2017.10.001

ANANTHANARAYAN, L., GAT, Y., PANGHAL, A., CHHIKARA, N., SHARMA, P., KUMAR, V., \& SINGH, B. 2018b. Effect of extrusion on thermal, textural and rheological properties of legume based snack. Journal of food science and technology, 1-8. https://doi.org/10.1007/s13197-018-3306-8

ANTON, A. A., ARTFIELD, S. D. 2008. Hydrocolloids in gluten-free breads: a review. International journal of food sciences and nutrition, 59(1), 11-23. https://doi.org/10.1080/09637480701625630

AOAC. Official Methods of Analysis of the Association of Official Analytical Chemists,. 16th ed., P. Cunniff (Ed.). Association of Official Analytical Chemists Inc., Arlington, Va. 1995

AOAC. Official methods of analysis. Assoc. Offic. Anal. Chem. Int Gaithersburg. 2006

AZIAH, N. A., NOOR, M. A., HO, L. H. 2012. Physicochemical and organoleptic properties of cookies incorporated with legume flour. International Food Research Journal, 19(4), 1539

BILGIN, B., DAGLIOGLU, O., KONYALI, M. 2006. Functionality of bread made with pasteurized whey and/or buttermilk. Italian journal of food science, $18(3)$

CHAVAN, M., GAT, Y., HARMALKAR, M., WAGHMARE, R. 2018 Development of non-dairy fermented probiotic drink based on germinated and ungerminated cereals and legume. FOOD SCIENCE AND TECHNOLOGY ZURICH-, 91(1), 339-344. https://doi.org/10.1016/i.lwt 2018.01.070

CHEFTEL, J. C. 1986. Nutritional effects of extrusion-cooking. Food chemistry, 20(4), 263-283. https://doi.org/10.1016/0308-8146(86)90096-8

CRESSEY, P. J., CAMPBELL, W. P., WRIGLEY, C. W., GRIFFIN, W. B 1987. Statistical correlations between quality attributes and grain-protein composition. Cereal Chem, 64(4), 299-301

DEMIRKESEN, I., MERT, B., SUMNU, G., SAHIN, S. 2010. Rheologica properties of gluten-free bread formulations. Journal of food Engineering, 96(2), 295-303. https://doi.org/10.1016/i.jfoodeng.2009.08.004

FRANCIS, F. J. 1998. Color analysis. Food analysis, 3

GALLAGHER, E., KUNKEL, A., GORMLEY, T. R., ARENDT, E. K. 2003 The effect of dairy and rice powder addition on loaf and crumb characteristics, and on shelf life (intermediate and long-term) of gluten-free breads stored in a modified atmosphere. European Food Research and Technology, 218(1), 44-48. https://doi.org/10.1007/s00217-003-0818-9

GAT, Y., ANANTHANARAYAN, L. 2015a. Effect of extrusion process parameters and pregelatinized rice flour on physicochemical properties of readyto-eat expanded snacks. Journal of food science and technology, 52(5), 2634 2645. https://doi.org/10.1007/s13197-014-1378-7

GAT, Y., \& ANANTHANARAYAN, L. (2015b). Physicochemical, phytochemical and nutritional impact of fortified cereal-based extrudate snacks. Nutrafoods, 14(3), 141-149. https://doi.org/10.1007/s13749-015-0036-

GAT, Y., \& ANANTHANARAYAN, L. (2016). Use of paprika oily extract as pre-extrusion colouring of rice extrudates: impact of processing and storage on colour stability. Journal of food science and technology, 53(6), 2887-2894 https://dx.doi.org/10.1007\%2Fs13197-016-2271-3

GHODKE, S. K. (2009). Effect of guar gum on dough stickiness and staling in Chapatti-An Indian unleavened flat bread. International journal of food engineering, 5(3). https://doi.org/10.2202/1556-3758.1317

HSU, D., LEUNG, H. K., FINNEY, P. L., \& MORAD, M. M. (1980). Effect of germination on nutritive value and baking properties of dry peas, lentils, and faba beans. Journal of Food Science, 45(1), 87-92. https://doi.org/10.1111/j.1365 2621.1980.tb03877.x

JAFARI, M., KOOCHEKI, A., \& MILANI, E. (2018). Physicochemical and sensory properties of extruded sorghum-wheat composite bread. Journal of Food 
Measurement and Characterization, 12(1), 370-377. https://doi.org/10.1007/s11694-017-9649-4

JYOTSNA, R., SAKHARE, S. D., INAMDAR, A. A., \& Rao, G. V. (2014). Effect of Green Gram Semolina (Phaseolus aureus) on the Rheology, Nutrition, Microstructure and Quality Characteristics of High-Protein Pasta. Journal of food processing and preservation, 38(4), 1965-1972. https://doi.org/10.1111/jfpp.12172

KOHAJDOVÁ, Z., KAROVICOVA, J., \& SCHMIDT, S. (2009). Significance of emulsifiers and hydrocolloids in bakery industry. Acta Chimica Slovaca, 2(1), 46-61

MARTÍNEZ, M. M., OLIETE, B., ROMÁN, L., \& GÓMEZ, M. (2014). Influence of the addition of extruded flours on rice bread quality. Journal of food quality, 37(2), 83-94. https://doi.org/10.1111/jfq.12071

MENEGASSI, B., PILOSOF, A. M., \& ARÊAS, J. A. (2011). Comparison of properties of native and extruded amaranth (Amaranthus cruentus L.-BRS Alegria) flour. LWT-Food Science and Technology,44(9), 1915-1921. https://doi.org/10.1016/j.lwt.2011.04.008

MOSTAFA, M. M., RAHMA, E. H., \& RADY, A. H. (1987). Chemical and nutritional changes in soybean during germination. Food Chemistry, 23(4), 257 275. https://doi.org/10.1016/0308-8146(87)90113-0

NUESSLI, J., HANDSCHIN, S., CONDE-PETIT, B., \& ESCHER, F. (2000). Rheology and structure of amylopectin potato starch dispersions without and with emulsifier addition. Starch-Stärke, 52(1), 22-27. https://doi.org/10.1002/(SICI)1521-379X(200001)52:1<22::AID-

STAR22>3.0.CO;2-I

ORTOLAN, F., BRITES, L. T. G., MONTENEGRO, F. M., SCHMIELE, M., STEEL, C. J., CLERICI, M. T. P., CHANG, Y. K. (2015). Effect of extruded wheat flour and pre-gelatinized cassava starch on process and quality parameters of French-type bread elaborated from frozen dough. Food Research International, 76, 402-409. https://doi.org/10.1016/j.foodres.2015.07.010

OTTO, M. (1999). Chemometrics: statistics and computer application in analytical chemistry. John Wiley \& Sons.

OUAZIB, M., DURA, A., ZAIDI, F., \& ROSELL, C. M. (2016). Effect of partial substitution of wheat flour by processed (Germinated, Toasted, Cooked) chickpea on bread quality. International Journal of Agricultural Science and Technology. https://doi.org/10.12783/ijast.2016.0401.02

OZOLA, L., STRAUMITE, E., GALOBURDA, R., \& KLAVA, D. (2012)

Application of extruded maize flour in gluten-free bread formulations. World Academy of Science, Engineering and Technology, 64(4), 883-888

ROMÁN, L., SANTOS, I., MARTÍNEZ, M. M., \& GOMEZ, M. (2015). Effect of extruded wheat flour as a fat replacer on batter characteristics and cake quality. Journal of food science and technology,52(12), 8188-8195. https://doi.org/10.1007/s13197-015-1909-x

SHALINI, K. G., \& LAXMI, A. (2007). Influence of additives on rheological characteristics of whole-wheat dough and quality of Chapatti (Indian unleavened Flat bread) Part I-hydrocolloids. Food hydrocolloids, 21(1), 110-117. https://doi.org/10.1016/j.foodhyd.2006.03.002

VAN RIEMSDIJK, L. E., VAN DER GOOT, A. J., HAMER, R. J., \& BOOM, R M. (2011). Preparation of gluten-free bread using a meso-structured whey protein particle system. Journal of Cereal Science,53(3), 355-361. https://doi.org/10.1016/j.jcs.2011.02.006

YOUSIF, M. R. G., \& SAFAA, M. (2014). Supplementation of gluten-free bread with some germinated legumes flour. Journal of American Science, 10(3), 84-93 